\title{
Effects of dietary supplementation of leaves and whole plant of Andrographis paniculata on rumen fermentation, fatty acid composition and microbiota in goats
}

\author{
Aisha L. Yusuf ${ }^{1,5}$, Kazeem D. Adeyemi ${ }^{1,6}$, Anjas A. Samsudin ${ }^{1}$, Yong M. Goh ${ }^{4}$, Abdul Razak Alimon ${ }^{1}$
} and Awis Q. Sazili $1,2,3^{*}$

\begin{abstract}
Background: The nature and amount of dietary medicinal plants are known to influence rumen fermentation and nutrient digestibility in ruminants. Nonetheless, changes in nutrient digestibility and rumen metabolism in response to dietary Andrographis paniculata (AP) in goats are unknown. This study examined the effects of dietary supplementation of leaves and whole plant of AP on nutrient digestibility, rumen fermentation, fatty acids and rumen microbial population in goats. Twenty-four Boer crossbred bucks (4 months old; average body weight of 20. $18 \pm 0.19 \mathrm{~kg}$ ) were randomly assigned to three dietary groups of eight goats each. The dietary treatments included a control diet (Basal diet without additive), basal diet $+1.5 \%(\mathrm{w} / \mathrm{W})$ Andrographis paniculata leaf powder (APL) and basal diet $+1.5 \%(\mathrm{w} / \mathrm{w})$ Andrographis paniculata whole plant powder (APW). The trial lasted $100 \mathrm{~d}$ following $14 \mathrm{~d}$ of adjustment.

Results: The rumen $\mathrm{pH}$ and concentration of propionate were greater $(P<0.05)$ in goats fed the APL and APW diets than those fed the control diet. The concentrations of ammonia nitrogen and acetate were greater $(P<0.05)$ in the control goats than the APL and APW goats. The digestibilities of crude protein, dry matter, acid detergent fibre and neutral detergent fibre were greater $(P<0.05)$ in the APL and APW goats compared to the control goats. Dietary APL and APW decreased $(P<0.05)$ the ruminal concentration of C18:0 and increased $(P<0.05)$ the ruminal concentration of $C 18: 2 n-6$ and $C 18: 3 n-3$. The APL goats had greater $(P<0$. 05) ruminal concentration of $\mathrm{C} 18: 1$ trans-11 and CLA cis-9 trans-11 than the APW and control goats. Dietary treatments had no significant effect on the population of protozoa and methanogens in the rumen of goats. The ruminal populations of Ruminococcus albus, Ruminococcus flavefaciens and Fibrobacter succinogenes were greater $(P<0.05)$ in the APL and APW goats than the control goats.
\end{abstract}

Conclusion: Dietary supplementation of leaves and whole plant of Andrographis paniculata can be used to manipulate rumen metabolism for improved nutrient digestibility in goats.

Keywords: Nutrient digestibility, Ruminococcus albus, Ruminococcus flavefaciens, Fibrobacter succinogenes

\footnotetext{
* Correspondence: awis@upm.edu.my; awisqurni@gmail.com

1 Department of Animal Science, Faculty of Agriculture, Universiti Putra

Malaysia, 43400 UPM Serdang, Selangor Darul Ehsan, Malaysia

2Laboratory of Sustainable Animal Production and Biodiversity, Institute of

Tropical Agriculture and Food Security, Universiti Putra Malaysia, 43400 UPM

Serdang, Selangor Darul Ehsan, Malaysia

Full list of author information is available at the end of the article
} 


\section{Background}

The manipulation of the rumen ecosystem is an important strategy for ensuring efficient feed utilization in ruminants [1, 2]. Improved feed efficiency could help to achieve the desired production targets with minimal negative impact on the environment $[2,3]$. Plant secondary metabolites (PSM) in medicinal plants are capable of manipulating rumen metabolism and this could have environmental and production merits or demerits [2-6]. The major factors influencing the effects of PSMs in ruminant nutrition are the chemical nature of PSMs, their concentration in diet and the diversity and abundance of rumen microbiota [2-6].

A plethora of studies has examined the impact of supplementing myriad PSMs on rumen metabolism and nutrient digestibility in ruminants $[2,3,5,6]$. However, there are wide variations in outcome between different studies. Therefore, there is need for additional studies in different production systems to permit tailored decisions and informed choices in the utilization of PSMs in ruminant nutrition.

Andrographis paniculata (AP), called 'king of bitters' is a medicinal plant that is native to Asia [7]. The PSMs in different parts of AP [7-9] and the effects of AP on in vitro rumen metabolism [9] and growth performance in goats [10] have been documented. However, information regarding the effects of AP on in vivo rumen metabolism and nutrient digestibility in ruminants is very scarce. In addition, the response of rumen microbiota to dietary AP is unknown. Thus, the objective of this study was to determine the effects of dietary AP on nutrient digestibility, rumen fermentation and the population of rumen microbiota in goats.

\section{Methods}

\section{Animals and diets}

Twenty-four Boer bucks (4 months old, with average initial body weight of $20.18 \pm 0.19 \mathrm{~kg}$ ) were used for this trial. Each goat was housed in individual pen $(1.20 \mathrm{~m} \times 0.80 \mathrm{~m} \times 0.70 \mathrm{~m})$ furnished with drinking and feeding facilities. The goats were treated against endo and ectoparasites prior to the commencement of the trial. The goats were randomly assigned to three dietary groups of eight goats each. The experimental diets were formulated to meet the nutritional requirements of growing goats in line with the NRC [11] recommendations. The dietary treatments included a control diet (basal diet without additive), a basal diet $+1.5 \%(w / w)$ Andrographis paniculata leaf powder (APL) and a basal diet $+1.5 \%$ (w/w) Andrographis paniculata whole plant powder (APW). The additives were incorporated into the concentrate portion of the diet. The experimental diets were offered as complete ration mix (forage and concentrate) in two equal meals at 0830 and $1430 \mathrm{~h}$. All goats had ad libitum access to water. The experiment lasted $100 \mathrm{~d}$ following two weeks of adaptation.

\section{Feed analysis}

Feed samples (400 g) were collected weekly and stored at $-20{ }^{\circ} \mathrm{C}$ until analysis. Feed samples were dried at $60^{\circ}$ $\mathrm{C}$ for $48 \mathrm{~h}$ to determine the DM content, ground to pass through a $1 \mathrm{~mm}$ screen and analysed for ash, ether extract and crude protein according to the methods of AOAC [12]. The neutral detergent fibre (NDF) and acid detergent fibre (ADF) were analysed by the protocol of Van Soest et al. [13]. The ingredients and proximate composition of the experimental diets are presented in Table 1 while the fatty acid composition of the dietary treatments is presented in Table 2.

\section{Apparent nutrient digestibility trial}

The apparent nutrient digestibility trial was conducted between $\mathrm{d} 70$ and 90 of the trial $(10 \mathrm{~d}$ for adaptation and $10 \mathrm{~d}$ for faecal collection). Each animal in each treatment was housed in a metabolic crate measuring $1.20 \mathrm{~m} \times 0.5 \mathrm{~m} \times 0.90 \mathrm{~m}$ each, and furnished with drinking and feeding facilities. The daily feed allowance was offered in two equal meals at 0830 and $1430 \mathrm{~h}$. All goats had ad libitum access to water. Daily dry matter intake (DMI) was estimated as the arithmetic difference between the offered and refused dry matter. Daily feces from individual animal was collected and weighed in the

Table 1 Ingredients and chemical composition of dietary treatments

\begin{tabular}{llll}
\hline & \multicolumn{3}{l}{ Dietary treatments } \\
\cline { 2 - 4 } Ingredient (\%) & Control & APL & APW \\
\hline Oil palm frond & 40.00 & 40.00 & 40.00 \\
Rice husk & 10.00 & 10.00 & 10.00 \\
Napier grass & 10.00 & 10.00 & 10.00 \\
Concentrate & 40.00 & 40.00 & 40.00 \\
APL & 0.00 & 1.50 & 0.00 \\
APW & 0.00 & 0.00 & 1.50
\end{tabular}

Chemical composition (\% DM)

$\begin{array}{llll}\text { Dry matter } & 89.86 & 89.88 & 89.89 \\ \text { Crude protein } & 16.79 & 16.79 & 16.79 \\ \text { Ether extract } & 5.89 & 5.80 & 5.80 \\ \text { Ash } & 5.04 & 5.15 & 5.16 \\ \text { Acid detergent fibre } & 30.10 & 30.94 & 30.98 \\ \text { Neutral detergent fibre } & 48.58 & 48.64 & 48.56 \\ \text { Calcium } & 1.41 & 1.41 & 1.41 \\ \text { Phosphorus } & 1.03 & 1.03 & 1.03 \\ \text { Metabolizable energy }(\mathrm{MJ} / \mathrm{kg} \mathrm{DM}) & 10.92 & 10.90 & 10.90\end{array}$

Control basal diet, APL basal diet $+1.5 \%$ (w/w) Andrographis paniculata leaf powder, $A P W$ basal diet $+1.5 \%(w / w)$ whole plant of Andrographis paniculata powder

acalculated 
Table 2 Fatty acid composition (\% of total fatty acid) of dietary treatments

\begin{tabular}{llll}
\hline & \multicolumn{3}{l}{ Dietary treatments } \\
\cline { 2 - 4 } Fatty acid (\%) & control & APL & APW \\
\hline C10:0 & 0.41 & 1.11 & 0.99 \\
C12:0 & 14.08 & 5.12 & 15.20 \\
C14:0 & 6.90 & 5.98 & 5.63 \\
C15:0 & 0.11 & 0.06 & 0.07 \\
C16:0 & 18.21 & 17.50 & 17.42 \\
C16:1 & 0.23 & 0.22 & 0.31 \\
C17:0 & 0.27 & 0.19 & 0.19 \\
C18:0 & 4.72 & 4.19 & 4.43 \\
C18:1 n-9 & 24.06 & 24.09 & 24.05 \\
C18:2 n-6 & 25.66 & 26.20 & 26.25 \\
C18:3 n-3 & 5.55 & 5.65 & 5.49 \\
¿SFA & 44.70 & 44.15 & 43.93 \\
EUSFA & 55.50 & 55.94 & 56.07 \\
n6:n3 & 4.62 & 4.63 & 4.78 \\
\hline Contol & &
\end{tabular}

Control basal diet, APL basal diet $+1.5 \%(\mathrm{w} / \mathrm{w})$ Andrographis paniculata leaf powder, APW basal diet $+1.5 \%(\mathrm{w} / \mathrm{w})$ whole plant of Andrographis paniculata powder. $\Sigma \mathrm{SFA}=(\mathrm{C} 10: 0+\mathrm{C} 12: 0+\mathrm{C} 14: 0+\mathrm{C} 15: 0+\mathrm{C} 16: 0+\mathrm{C} 17: 0+\mathrm{C} 18: 0)$, $\Sigma U F A=(C 16: 1+C 18: 1+C 18: 2 n-6+C 18: 3 n-3), n-6: n-3=(C 18: 2 n-6 \div C 18: 3 n-3)$

morning before feeding. After thorough mixing, approximately $50 \mathrm{~g} / \mathrm{Kg}$ of the daily feces from each animal were sampled and stored at $-20{ }^{\circ} \mathrm{C}$ for subsequent analyses.

\section{Collection of rumen fluid}

About $50 \mathrm{~mL}$ of rumen liquor was collected from each goat after $2 \mathrm{~h}$ of feeding by aspiration using stomach tube. The rumen fluid $\mathrm{pH}$ was immediately measured using the Mettler-Toledo $\mathrm{pH}$ meter. The rumen fluid was strained through four layers of cheesecloth and $5 \mathrm{~mL}$ of $1 \mathrm{M} \mathrm{H}_{2} \mathrm{SO}_{4}$ was added. The rumen fluid was snap frozen in liquid nitrogen and stored at $-80^{\circ} \mathrm{C}$ until further analyses.

\section{Determination of volatile fatty acids (VFA) in rumen liquor}

The rumen liquor was fixed with $25 \%(\mathrm{v} / \mathrm{v})$ metaphosphoric acid and centrifuged at $4000 \mathrm{~g}$. The supernatant $(0.5 \mathrm{~mL})$ was collected and added to $0.5 \mathrm{~mL}$ of $20 \mathrm{mM}$ valeric acid. The VFA content of the rumen fluid was determined using gas chromatography as described by Yusuf et al. [9]. The sample peaks were identified by comparing with authentic VFA standards.

\section{Determination of ammonium nitrogen in rumen liquor}

Ammonium nitrogen was determined as described by Parsons et al. [14]. A Standard solution was prepared using ammonium chloride $\left(\mathrm{NH}_{4} \mathrm{Cl}\right)$ by dissolving $1.908 \mathrm{~g}$ of $\mathrm{NH}_{4} \mathrm{Cl}$ in $500 \mathrm{~mL}$ distilled water, which gave $1000 \mathrm{mg}$ $/ \mathrm{L}$ ammonia-N. Thereafter, $0.2,0.5,1.0$ and $2.0 \mathrm{ppm}$ solutions were prepared by dissolving $0.02,0.05,0.10$ and $0.20 \mathrm{~mL}$ of the stock solution into $100 \mathrm{~mL}$ of distilled water, respectively. Approximately $5 \mathrm{~mL}$ standard was added into an Erlenmeyer flask containing $0.2 \mathrm{~mL}$ phenol solution and swirled. In sequence, $0.2 \mathrm{~mL}$ nitroprusside and $0.5 \mathrm{~mL}$ of oxidizing solution were added, thoroughly mixed and allowed to stand for $24 \mathrm{~h}$. The absorbance was determined at $640 \mathrm{~nm}$ using SC spectrophotometer (Labomed Inc., Culver City, CA, USA). Regression equation was determined from the blank and standard samples and ammonia- $\mathrm{N}$ was estimated in the samples.

\section{Determination of fatty acid (FA) composition}

The total FA in feed and rumen liquor was extracted in chloroform: methanol mixture $(2: 1, v / \mathrm{v})$ following the method Folch et al. [15]. The extracted fat was transmethylated into their fatty acid methyl esters (FAME) using $0.66 \mathrm{~N} \mathrm{KOH}$ in methanol and $14 \%$ methanolic boron trifluoride $\left(\mathrm{BF}_{3}\right)$ according to the protocol of AOAC [12]. The separation of the FAME was done with a gas chromatograph (Model 6890 Agilent Technologies, USA). The gas chromatograph settings and quantification of FA was done as described by Adeyemi et al. [16].

\section{Extraction of DNA from rumen microbes}

Total bacteria DNA in the rumen was extracted using the QIAamp ${ }^{\circ}$ mini stool kit (QIAGEN, Hilden, GmbH) following the manufacturer's protocol with slight modification as described by Khaing et al. [17].

\section{Quantitative real-time PCR}

A standard curve method in real-time PCR was used to quantify rumen bacteria, protozoa and methanogenic populations. The standard curves were constructed using the number of copies of the 16S rRNA gene plotted against quantification cycle $(\mathrm{Cq})$ that was obtained from ten-fold serial dilutions of PCR products from a pure culture of each group of rumen microorganism. The DNA was extracted from the pure culture of each targeted rumen microorganisms in order to prepare the standard curves. The bacterial DNA was amplified using conventional PCR. The PCR products of the targeted rumen microorganisms were run in $1 \%$ agarose gel and specific bands were purified using the mEGAquickspinTM purification kit. The concentration and purity of 16S rRNA gene in each sample was determined using a NanoDrop ND-1000 UV-Vis Spectrophotometer (NanoDrop Technologies, Wilmington, DE, USA) at $260 / 280 \mathrm{~nm}$ absorbance. The number of copies of the 16S-rRNA gene per $\mathrm{mL}$ of elution buffer was quantified using the formula obtained online in URI Genomics and Sequencing Centre web-based calculator (www.uri.edu/ research/gsc/resources/cndna.html). 
Number of copies $=\frac{\text { Amount of DNA }(\mu \mathrm{g} / \mathrm{mL}) \times 6.022 \times 10^{23}}{\text { Length }(\mathrm{bp}) \times 10^{9} \times 650}$

Since the amplification efficiency among templates and primers may be variable, the amplification Efficiency (E) of each primer-template combination was estimated based on the slope value of the linear regression of each standard curve determined by the equation below:

$$
E(\%)=\left[10^{(-1 / \text { slope })}-1\right] \times 100
$$

Where $\mathrm{E}$ is $100 \%$ if a ten-fold dilution of DNA template results in a Cq difference of 3.32 .

The sequences and primers used to quantify the number of different microbes are shown in Table 3. The Real-time PCR was conducted with the Bio-Rad CFX96 Touch (Bio-Rad Laboratories, Hercules, CA, USA) using optical grade plates. The PCR reaction was performed on a total volume of $25 \mu \mathrm{L}$ using the iQTMSYBR Green Supermix (Bio-Rad Laboratories, Hercules, CA, USA). Each reaction included $12.5 \mu \mathrm{L}$ SYBR Green Supermix, $1 \mu \mathrm{L}$ of forward primer $(10 \mu \mathrm{M}), 1 \mu \mathrm{L}$ of reverse primer $(10 \mu \mathrm{M}), 2 \mu \mathrm{L}$ of DNA samples and $8.5 \mu \mathrm{L}$ RNAse free water. The conditions applied to each well included an initial incubation at $94{ }^{\circ} \mathrm{C}$ for $5 \mathrm{~min} ; 40$ cycles of denaturation for $20 \mathrm{~s}$ at $94{ }^{\circ} \mathrm{C}$ annealing for $30 \mathrm{~s}$ and for $20 \mathrm{~s}$ at $72{ }^{\circ} \mathrm{C}$. A melting curve analysis was conducted after the last cycle of each amplification to confirm the specificity of amplification.

\section{Statistical analysis}

The data were analyzed in a completely randomized design using the MIXED procedure of SAS [22] with sampling time as a repeated measure. Dietary treatments, sampling time and the interaction between diet and sampling time were fitted as fixed effects while goats within treatments were fitted as random effects. The real-time PCR data did not meet the ANOVA requirement of normality. Thus, the data was subjected to logarithm transformation prior to subjecting it to the MIXED procedure of SAS [37]. Means were separated using the "PDIFF" option of the "LSMEANS" statement of the MIXED procedure. Dunnett's test was used to adjust the means. The level of significance difference was set at $P<0.05$. The statistical model used for the analyses was:

$$
y_{i j k}=\mu+\tau_{i}+\mathrm{d}_{\mathrm{ij}}+\mathrm{S}_{\mathrm{k}}+(\tau \mathrm{S})_{\mathrm{ik}}+\varepsilon_{i j k}
$$

Where $y_{i j k}=$ observation for a parameter.

$\mu=$ the overall mean.

$\tau_{i}=$ effect of dietary treatment $i$.

$\mathrm{d}_{\mathrm{ij}}=$ random effect of goats within treatment.

$\mathrm{S}_{\mathrm{k}}=$ effect of sampling time $k$.

$(\tau S)_{\mathrm{ik}}=$ interaction between dietary treatment and sampling time.

$\varepsilon_{i j k}=$ random error term.

\section{Results}

\section{Apparent nutrient digestibility}

Dry matter intake and digestibility, and apparent nutrient digestibility coefficients in goats fed different parts of AP are shown in Table 4. The digestibilities of DM, $\mathrm{CP}, \mathrm{NDF}$ and ADF were greater $(P<0.05)$ in the APL and APW goats than the control goats. Dietary AP had no significant effect $(P>0.05)$ on DMI and ether extract digestibility in goats.

\section{Rumen fermentation}

The rumen fermentation parameters in goats fed different parts of AP are presented in Table 5 . The rumen $\mathrm{pH}$ was lower $(P<0.05)$ in the control goats than the APL

\begin{tabular}{|c|c|c|c|c|}
\hline Microorganism & Sequence $5^{\prime}-3^{\prime}$ & Product size (bp) & Annealing temperature $\left({ }^{\circ} \mathrm{C}\right)$ & Reference \\
\hline Total bacteria F & CGGCAACGAGCGCAACCC & 145 & 55 & [18] \\
\hline Total bacteria $\mathrm{R}$ & CCATTGTAGCACGTGTGTAGCC & & & \\
\hline Total protozoa F & CTTGCCCTCYAATCGTWCT & 223 & 55 & [19] \\
\hline Total protozoa R & GCTITCGWTGGTAGTGTATT & & & \\
\hline Methanogens (mcrA)-F & TTCGGTGGATCDCARAGRGC & 140 & 55 & [20] \\
\hline Methanogens (mcrA)-R & GBARGTCGWAWCCGTAGAATCC & & & \\
\hline Fibrobacter succinogenes & GTTCGGAATTACTGGGCGTAAA & 122 & 55 & [21] \\
\hline Fibrobacter succinogenes & CGCCTGCCCCTGAACTATC & & & \\
\hline Ruminococcus albus & CCCTAA AAGCAGTCTTAGTTCG & 170 & 55 & [18] \\
\hline Ruminococcus albus & CCTCCTTGCGGTTAGAACA & & & \\
\hline Ruminococcus flavefaciens F (Rf154f) & TCTGGAAACGGATGGTA & 259 & 55 & [18] \\
\hline Ruminococcus flavefaciens (Rf425r) & CCTTTAAGACAGGAGTTACAA & & & \\
\hline
\end{tabular}

Table 3 Microorganisms, sequences and references for the primers used 
Table 4 Dry matter intake and nutrient digestibility (Least square means \pm standard error of mean) in goats fed diets containing different parts of Andrographis paniculata

\begin{tabular}{|c|c|c|c|c|}
\hline \multirow[b]{2}{*}{ Parameter } & \multicolumn{3}{|c|}{ Dietary treatments } & \multirow[b]{2}{*}{$P$ value } \\
\hline & Control & $\mathrm{APL}$ & APW & \\
\hline$\overline{\mathrm{DMI}}(\mathrm{g} / \mathrm{d})$ & $796.33 \pm 4.21$ & $816.10 \pm 5.23$ & $827.13 \pm 4.50$ & 0.08 \\
\hline DM digestibility (\%) & $61.87 \pm 0.04$ & $66.35^{+} \pm 0.03$ & $66.50^{+} \pm 0.01$ & 0.03 \\
\hline \multicolumn{5}{|l|}{ Nutrient digestibility (\%) } \\
\hline Crude protein & $43.98 \pm 1.57$ & $60.35^{+} \pm 1.55$ & $67.50^{+} \pm 0.07$ & 0.01 \\
\hline Ether extract & $62.71 \pm 1.10$ & $64.02 \pm 0.19$ & $64.85 \pm 0.30$ & 0.64 \\
\hline Acid detergent fibre & $39.42 \pm 0.24$ & $40.69^{+} \pm 0.14$ & $40.89^{+} \pm 0.10$ & 0.04 \\
\hline Neutral detergent fibre & $57.53 \pm 0.20$ & $60.32^{+} \pm 0.07$ & $60.50^{+} \pm 0.03$ & 0.02 \\
\hline
\end{tabular}

and APW goats. The concentration of ammonia nitrogen and the acetate/propionate ratio in the control goats were greater $(P<0.05)$ than that of the APL and APW goats. The control goats had greater $(P<0.05)$ concentration of acetate and lower $(P<0.05)$ concentration of propionate than the APL and APW goats. Dietary AP did not affect $(P>0.05)$ the concentration of total VFA and butyrate in the rumen of goats.

\section{Fatty acid composition of rumen liquor}

The fatty acid composition of rumen liquor in goats fed different parts of Andrographis paniculata is presented in Table 6. The percentages of C10:0, C14:0 and C15:1 in the rumen liquor of the control goats did not differ $(P>0.05)$ from that of the APL goats. The APW goats had lower $(P<0.05)$ percentages of C10:0, C14:0 and C15:1 than the control goats. Dietary supplementation of AP had no significant effect on the percentages of C15:0, C16:0, C17:0 and C18:1n-9 in the rumen of goats. The control goats had greater $(P<0.05)$ percentage of C18:0 than the APL and APW goats. The percentages of C18:1trans 11 and CLA cis-9 trans-11 in goats fed APL diet were greater $(P<0.05)$ than those fed the control and APW diets. The control and APW goats had similar percentages of C18:1trans 11 and CLA cis-9 trans- 11 . The APL and APW goats had greater $(P<0.05)$ percentages of C18:2n-6 and C18:3n-3 than the control goats. Ruminal total unsaturated fatty acids was greater $(P<0.05)$ while the total saturated fatty acids and n6:n3 ratio were lower $(P<0.05)$ in the APW goats than the control and APL goats.

\section{Rumen microbial populations}

The response of rumen microbial populations to dietary supplementation of AP is presented in Table 7. Dietary AP had no significant effect on the populations of protozoa, methanogens and total bacteria in the rumen of goats. The populations of Ruminococcus albus, Ruminococcus flavefaciens and Fibrobacter succinogenes were greater $(P<0.05)$ in the APW and APL goats than the control goats.

\section{Discussion}

The aim of this study was to determine the effects of dietary supplementation of leaves and whole plant of Andrographis paniculata on nutrient digestibility and rumen metabolism in goats. It was evident that dietary supplementation of APW and APL enhanced apparent

Table 5 Rumen fermentation profiles (Least square means \pm standard error of mean) in goats fed diets containing different parts of Andrographis paniculata

\begin{tabular}{lllll}
\hline & \multicolumn{2}{l}{ Dietary treatment } & & APW \\
\cline { 2 - 4 } Parameter & Control & APL & $6.25^{+} \pm 0.01$ & \\
\hline pH & $6.10 \pm 0.01$ & $6.25^{+} \pm 0.01$ & $19.10^{+} \pm 0.05$ & 0.02 \\
Ammonia $\left(\mathrm{mg} \mathrm{dL}^{-1}\right)$ & $22.05 \pm 0.01$ & $19.25^{+} \pm 0.42$ & $57.99 \pm 4.14$ & 0.02 \\
Total VFA (mM) & $63.09 \pm 2.44$ & $59.72 \pm 1.49$ & $35.02^{+} \pm 1.33$ & 0.39 \\
Acetate (mM) & $48.84 \pm 1.89$ & $38.00^{+} \pm 1.10$ & $20.00^{+} \pm 0.06$ & 0.01 \\
Propionate (mM) & $11.46 \pm 0.03$ & $18.44^{+} \pm 0.08$ & $1.33 \pm 0.01$ & 0.03 \\
Butyrate $(\mathrm{mM})$ & $1.68 \pm 0.01$ & $1.48 \pm 0.01$ & $1.75^{+} \pm 0.01$ & 0.09 \\
Acetate/Propionate & $4.26 \pm 0.02$ & $2.06^{+} \pm 0.01$ & 0.01 \\
\hline
\end{tabular}

Control basal diet, APL basal diet $+1.5 \%(w / w)$ Andrographis paniculata leaf powder, APW basal diet $+1.5 \%$ (w/w) whole plant of Andrographis paniculata powder ${ }^{+}$Differ from the control $(P<0.05)$ 
Table 6 Fatty acid composition (Least square means \pm standard error of mean) of rumen liquor in goats fed different parts of Andrographis paniculata

\begin{tabular}{|c|c|c|c|c|}
\hline \multirow{2}{*}{$\begin{array}{l}\text { Fatty acid } \\
\text { ( } \% \text { of total FA) }\end{array}$} & \multicolumn{3}{|c|}{ Dietary treatments } & \multirow[b]{2}{*}{$P$ value } \\
\hline & Control & APL & APW & \\
\hline$\overline{C 10: 0}$ & $0.06 \pm 0.01$ & $0.06 \pm 0.02$ & $0.02^{+} \pm 0.01$ & 0.02 \\
\hline $\mathrm{C} 12: 0$ & $8.55 \pm 0.27$ & $6.77^{+} \pm 0.29$ & $4.63^{+} \pm 0.34$ & 0.01 \\
\hline C14:0 & $8.86 \pm 0.12$ & $8.72 \pm 0.17$ & $6.15^{+} \pm 0.16$ & 0.01 \\
\hline C14:1 & $0.70 \pm 0.01$ & $0.78^{+} \pm 0.03$ & $0.70 \pm 0.02$ & 0.02 \\
\hline C15:0 & $0.61 \pm 0.02$ & $0.56 \pm 0.02$ & $0.62 \pm 0.06$ & 0.78 \\
\hline C15:1 & $0.27 \pm 0.01$ & $0.21 \pm 0.04$ & $0.09^{+} \pm 0.02$ & 0.01 \\
\hline C16:0 & $20.39 \pm 0.18$ & $20.41 \pm 0.49$ & $18.64 \pm 1.09$ & 0.33 \\
\hline C16:1 & $0.51 \pm 0.08$ & $0.76^{+} \pm 0.10$ & $0.83^{+} \pm 0.08$ & 0.04 \\
\hline C17:0 & $0.44 \pm 0.01$ & $0.41 \pm 0.04$ & $0.49 \pm 0.13$ & 0.11 \\
\hline C18:0 & $36.64 \pm 0.55$ & $32.73^{+} \pm 0.57$ & $27.01^{+} \pm 1.34$ & 0.01 \\
\hline C18:1n-9 & $3.53 \pm 0.25$ & $4.68 \pm 0.89$ & $6.61 \pm 2.08$ & 0.21 \\
\hline C18:1trans 11 & $2.75 \pm 0.12$ & $3.26^{+} \pm 0.37$ & $2.65 \pm 0.39$ & 0.02 \\
\hline CLA cis-9 trans-11 & $0.45 \pm 0.01$ & $0.72^{+} \pm 0.01$ & $0.51 \pm 0.05$ & 0.01 \\
\hline$C 18: 2 n-6$ & $1.39 \pm 0.17$ & $3.43^{+} \pm 0.32$ & $5.26^{+} 0.56$ & 0.03 \\
\hline$C 18: 3 n-3$ & $0.18 \pm 0.01$ & $0.51^{+} \pm 0.04$ & $0.81^{+} \pm 0.43$ & 0.01 \\
\hline$\Sigma S F A$ & $78.56 \pm 0.49$ & $74.66+0.76$ & $67.55^{+} 1.88$ & 0.03 \\
\hline$\Sigma U F A$ & $21.44 \pm 0.49$ & $25.34 \pm 0.76$ & $32.45^{+} \pm 1.23$ & 0.04 \\
\hline n6:n3 & $7.72 \pm 0.45$ & $7.31 \pm 0.22$ & $6.49^{+} \pm 0.48$ & 0.02 \\
\hline
\end{tabular}

Control basal diet, APL basal diet $+1.5 \%$ (w/w) Andrographis paniculata leaf powder, APW basal diet $+1.5 \%(\mathrm{w} / \mathrm{w})$ whole plant of Andrographis paniculata powder. $\Sigma$ SFA $=(\mathrm{C} 10: 0+\mathrm{C} 12: 0+\mathrm{C} 14: 0+\mathrm{C} 15: 0+\mathrm{C} 16: 0+\mathrm{C} 17: 0+\mathrm{C} 18: 0)$, $\Sigma \mathrm{UFA}=(\mathrm{C} 14: 1+\mathrm{C} 16: 1+$

$C 18: 1+C 18: 2 n-6+C 18: 3 n-3), n-6: n-3=(C 18: 2 n-6 \div C 18: 3 n-3)$

${ }^{+}$Differ from control $(P<0.05)$

nutrient digestibility in goats. The increased DM, NDF and ADF digestibilities could be due to the increase in the populations of Ruminococcus albus, Ruminococcus flavefaciens and Fibrobacter succinogenes in the rumen of goats fed AP diets. The increase in CP digestibility in the AP-supplemented goats could be due to the tannin present in AP [9], which protected the dietary protein from ruminal degradation. This observation lends credence to the lower concentration of ammonia nitrogen in the rumen of goats fed the AP diets. Similarly, dietary supplementation of various medicinal herbs enhanced nutrient digestibility in goats [23] and lambs [6]. Contrarily, dietary supplementation of Pakar (Ficus infectoria) leaves reduced nutrient digestibility in goats [24]. The similarity in the DMI of the goats suggests that AP did not reduce feed palatability in goats.

The ruminal concentration of ammonia nitrogen is an effective indicator of microbial activity in the rumen [17]. The minimum concentration of ammonia nitrogen needed for microbial protein synthesis is $5 \mathrm{mg} \mathrm{dL}^{-1}$ [25] while ammonia nitrogen concentration in the range of $10-20 \mathrm{mg} \mathrm{dL}^{-1}$ is needed for optimum fibre degradation in the rumen [26]. The level of ammonia nitrogen observed in the current study exceeded $5 \mathrm{mg} \mathrm{dL}^{-1}$ and ranged between 19.10 and $22.05 \mathrm{mg} \mathrm{dL}^{-1}$. This observation indicates that the concentrations of ammonia nitrogen observed following the supplementation of the dietary treatments were adequate for optimum microbial growth and rumen fermentation.

Dietary supplementation of AP reduced the concentration of ammonia nitrogen in the rumen of goats. This observation attests to the ability of AP polyphenols to protect dietary protein from microbial degradation. The current finding concurs with that of Singh et al. [24] who found a significant reduction in the concentration of ammonia nitrogen in goats fed Pakar leaves compared with those fed the basal diet. Similarly, dietary Lotus corniculatus [27] and sainfoin [28] reduced the concentration of ammonia nitrogen in the rumen of sheep. However, dietary Oak (Quercus libani Oliv.) did not affect the concentration of ammonia nitrogen in sheep [29].

The $\mathrm{pH}$ is an effective indicator of rumen metabolism [17]. The rumen $\mathrm{pH}$ observed in the current study ranged from 6.10 to 6.25 , and it is ideal for optimum rumen metabolism [17]. The APL and APW goats had

Table 7 Rumen microbial profile (Least square means \pm standard error of mean) in goats fed diets containing different parts of Andrographis paniculata

\begin{tabular}{|c|c|c|c|c|}
\hline \multirow[t]{3}{*}{ Parameters } & \multicolumn{4}{|c|}{$\log _{10}$ cell mL ${ }^{-1}$} \\
\hline & \multicolumn{3}{|c|}{ Dietary treatments } & \multirow[b]{2}{*}{$P$ value } \\
\hline & Control & APL & APW & \\
\hline Total bacteria & $10.57 \pm 0.20$ & $10.83 \pm 0.22$ & $10.97 \pm 0.21$ & 0.45 \\
\hline Total methanogens & $5.50 \pm 0.66$ & $5.01 \pm 0.81$ & $4.36 \pm 0.66$ & 0.23 \\
\hline Ruminococcus albus & $6.81 \pm 0.45$ & $8.08^{+} \pm 0.53$ & $8.38^{+} \pm 0.47$ & 0.03 \\
\hline Ruminococcus flavefaciens & $5.46 \pm 0.21$ & $5.98^{+} \pm 0.23$ & $6.55^{+} \pm 0.22$ & 0.04 \\
\hline Fibrobacter succinogenes & $3.88 \pm 0.25$ & $4.50^{+} \pm 0.28$ & $4.71^{+} \pm 0.23$ & 0.04 \\
\hline Total protozoa & $5.82 \pm 0.52$ & $5.49 \pm 0.61$ & $5.31 \pm 0.55$ & 0.12 \\
\hline
\end{tabular}

Control basal diet, APL basal diet $+1.5 \%$ (w/w) Andrographis paniculata leaf powder, APW basal diet $+1.5 \%$ (w/w) whole plant of Andrographis paniculata powder ${ }^{+}$Differ from the control $(P<0.05)$ 
greater rumen $\mathrm{pH}$ than the control goats. This finding could be due to the increase in the production of saliva and/or changes in saliva composition induced by the tannins present in the AP. Saliva serves as an important buffering capacity in the rumen [30]. An increase in salivary flow has been associated with the consumption of tanniferous feeds. For instance, Salem et al. [31] reported that the consumption of quebracho tannins increased the quantity of parotid saliva produced by goats and sheep as the supplementation period progressed. Contrary to the current observation, dietary Oak [29] and Pakar leaves [24] had no effect on rumen $\mathrm{pH}$ in sheep and goats respectively.

Dietary AP did not affect the total VFA in the rumen of goats. A similar observation was reported following dietary supplementation of Pakar leaves in goats [24]. Contrarily, condensed tannin reduced total VFA, while mangosteen peel [32] and rain pod tree [33] increased total VFA when supplemented. Dietary AP increased the concentration of propionate and reduced the concentration of acetate in the rumen of goats. This observation agrees with the report of earlier studies wherein, the supplementation of mangosteen peel [32] and rain pod tree [33] increased the concentration of propionate and decreased the concentration of acetate.

Regardless of the dietary treatments, the most abundant FA in the rumen liquor of goats was C18:0 followed by $\mathrm{C} 16: 0$. Similar findings were obtained in the in vitro [9] and in vivo rumen FA profile of goats [34]. Dietary supplementation of AP reduced the percentage of C18:0 in the rumen liquor of goats. Stearic acid is the final product of biohydrogenation of unsaturated fatty acids [35]. The lower proportion of C18:0 in the rumen of goats fed AP diets could be due to the selective antimicrobial activity of AP $[7,8]$, which hindered the growth and/or metabolism of microbes responsible for the complete biohydrogenation of unsaturated FA. It has been reported that the activities of Butyrovibrio proteoclasticum, the bacterium responsible for the biosynthesis of stearic acid from linoleic acid could be weakened by polyphenols, which have the capacity to bind microbial cell membrane, protein and enzymes [36]. The current finding is consistent with those of Khiaosa-Ard et al. [37] and Vasta et al. [38] who observed that tanninferous diets reduced ruminal concentration of C18:0.

Dietary APL and APW enhanced the percentage of C18:2n-6 and C18:3n-3 in the rumen liquor of goats. This observation suggests that AP reduced ruminal lipolysis of polyunsaturated fatty acids (PUFA) in goats. Polyphenols can bind both plant and microbial lipases and inhibit lipolysis and biohydrogenation of PUFA [39]. Jayanegara et al. [40] observed that phenolic compounds in tropical forages inhibited the in vitro biohydrogenation of C18:2n-6 and C18:3n-3 and reduced the production of C18:0. Contrarily, the supplementation of quebracho tannins did not affect the disappearance of C18:2n-6 and C18:3n-3 [5]. The APL goats had greater concentration of biohydrogenation intermediates (C18:1 trans-11 and CLA cis-9 trans-11) than the APW and control goats. This suggests that APL and APW differ in their effects on ruminal lipolysis and biohydrogenation of PUFA, possibly due to the differences in the polyphenol contents [9]. The effects of polyphenol on the concentration of biohydrogenation intermediates in the rumen have yielded inconsistent results in the published literature. The discrepancies were attributed to the chemical nature of polyphenols, intricate interactions between dietary components and the polyphenols and the adaptation of microbes to the polyphenols $[4,5]$. In addition, it has been suggested that the impact of polyphenols on biohydrogenation of unsaturated fatty acids depends on the biohydrogenation step that they affect [5]. Thus, it could be inferred that the APW diet exhibited greater inhibition on lipolysis and biohydrogenation of unsaturated fatty acids hence its lower concentration of biohydrogenation intermediates and $\mathrm{C} 18: 0$ and greater concentration of C18:2n-6 and C18:3n-3 when compared with the APL diet. The increase in the concentration of C18:1 trans- 11 and CLA cis-9 trans- 11 in the APL goats is consistent with the findings of Vasta et al. [5] who observed that the supplementation of quebracho tannins increased the ruminal concentration of C18:1 trans-11 in sheep. Similarly, phenolic compounds in tropical forages enhanced the appearance of CLA cis9 trans-11 but not C18:1 trans-11 [40].

Dietary AP had no significant effect on the populations of protozoa and methanogens in the rumen of goats. This finding suggests that the level of polyphenols in the AP diets [9] was not sufficient to reduce the populations of protozoa and methanogens. The response of protozoa and methanogens to the supplementation of medicinal herb has yielded inconsistent results in the published literature. Singh et al. [24] reported a reduction in rumen protozoa counts and an increase in methanogen counts in goats fed Pakar leaves. Tan et al. [41] observed that tannins in Leucaena leucocephala reduced the populations of protozoa and methanogens in vitro. Baah et al. [42] revealed that quebracho tannins reduced ruminal protozoa in heifers. However, Khiaosa-Ard et al. [37] observed that dietary tannins did not affect the total counts of protozoa and methanogens in the rumen.

The APL and APW diets increased the populations of Ruminococcus albus, Ruminococcus flavefaciens and Fibrobacter succinogenes in the rumen of goats. This finding could be due to the higher ruminal $\mathrm{pH}$, which encouraged the proliferation of the microbes. This observation could be responsible for the improved nutrient digestibility in the AP goats. Contrarily, Singh et al. [24] 
observed that dietary Pakar leaves had no effect on the population of total fungi and bacteria and Fibrobacter succinogenes but decreased the population of Ruminococcus flavefaciens. Thus, the current results suggest that the Ruminococcus albus, Ruminococcus flavefaciens and Fibrobacter succinogenes were able to tolerate the level of polyphenols present in the APL and APW [9].

\section{Conclusion}

The results of this study indicated that dietary APL and APW increased rumen $\mathrm{pH}$ and the concentration of propionate and reduced acetate concentration in goats. Dietary supplementation of AP enhanced the population of Ruminococcus albus, Ruminococcus flavefaciens and Fibrobacter succinogenes in the rumen and improved nutrient digestibility in goats. Further study to examine the impact of APL and APW on other groups of rumen microflora particularly those involved in lipid metabolism, and synthesis of other biohydrogenation intermediates is suggested.

\section{Abbreviations}

AP: Andrographis paniculata; APL: Andrographis paniculata leaves; APW: Andrographis paniculata whole plant; FA: Fatty acid; PUFA: Polyunsaturated fatty acid; VFA: Volatile fatty acid

\section{Acknowledgements}

None.

\section{Funding}

This research was funded by Universiti Putra Malaysia through Research University Grant Scheme Initiative 2 (Project No.: 01-02-12-1675RU) and Research University Grant Scheme Initiative 6 (Project No.: 01-02-11-1340RU).

\section{Availability of data and materials}

All data and materials are present in this manuscript.

\section{Authors' contributions}

Conceived and design the experiment: ALY, AQS, YMG, AAS ARA. Performed the experiment: ALY, KDA. Analyse the data: ALY, KDA. Contributed reagents/ materials: AQS, AAS, ARA, YMG. Wrote the manuscript: AYL, KDA, AQS. All authors read and approved the final manuscript.

\section{Ethics approval}

The experimental protocol followed the guidelines approved by the Institutional Animal Care and Use Committee (IACUC) of the Universiti Putra Malaysia.

\section{Consent for publication}

Not applicable

\section{Competing interests}

The authors declare that they have no competing interests.

\section{Publisher's Note}

Springer Nature remains neutral with regard to jurisdictional claims in published maps and institutional affiliations.

\section{Author details}

'Department of Animal Science, Faculty of Agriculture, Universiti Putra Malaysia, 43400 UPM Serdang, Selangor Darul Ehsan, Malaysia. ${ }^{2}$ Laboratory of Sustainable Animal Production and Biodiversity, Institute of Tropical Agriculture and Food Security, Universiti Putra Malaysia, 43400 UPM Serdang, Selangor Darul Ehsan, Malaysia. ${ }^{3}$ Halal Products Research Institute, Putra Infoport, Universiti Putra Malaysia, 43400 UPM Serdang, Selangor Darul Ehsan,
Malaysia. ${ }^{4}$ Department of Veterinary Preclinical Sciences, Faculty of Veterinary Medicine, Universiti Putra Malaysia, 43400 UPM Serdang, Selangor Darul Ehsan, Malaysia. ${ }^{5}$ Department of Animal Science, Usmanu Danfodiyo University, P.M.B, Sokoto 2346, Nigeria. ${ }^{6}$ Department of Animal Production, University of Ilorin, Ilorin, Nigeria.

Received: 3 May 2016 Accepted: 13 October 2017

Published online: 24 November 2017

\section{References}

1. Adeyemi KD, Ahmed MA, Jotham S, Roslan NA, Jahromi MF, Samsudin AA Sazili AQ. Rumen microbial community and nitrogen metabolism in goats fed blend of palm oil and canola oil. Italian J. Anim Sci. 2016;15:666-72.

2. Wanapat MAC, Pakdee P, Wanapat S. Manipulation of rumen ecology by lemon grass (Cymbopogon citratus stapf) powder supplementation. J Anim Sci. 2008:86:3497-503.

3. Carulla JE, Kreuzer M, Machmüller A, Hess HD. Supplementation of Acacia mearnsii tannins decreases methanogenesis and urinary nitrogen in foragefed sheep. Aust J Agric Res. 2005;56:961-70.

4. McSweeney C, Palmer B, McNeill D, Krause D. Microbial interactions with tannins: nutritional consequences for ruminants. Anim Feed Sci Technol. 2001;91:83-93

5. Vasta V, Yáñez-Ruiz DR, Mele M, Serra A, Luciano G, Lanza M, et al. Bacterial and protozoa communities and fatty acid profile in the rumen of sheep fed a diet containing added tannins. Appl Environ Microbiol. 2010;76:2549-55.

6. Ali MF, Saleh MF, Eweedah NM, Mohmoud SA. Effect of using chamomile (Mtricaria chamomilla) flowers as feed additives on performance of growing lambs under desert farming systems. Egypt J Nutr Feed. 2005;8:127-37.

7. Babeet ST, Choudhary R, Vijayvergia R. vivo and in-vitro comparative study of primary metabolites and antioxidant activity of Andrographis paniculata. J Chem Pharm Res. 2010:2:489-95.

8. Chandrasekaran CV, Thiyagarajan P, Deepak HB, Agarwal A. In vitro modulation of LPS/calcimycin induced inflammatory and allergic mediators by pure compounds of Andrographis paniculata (king of bitters) extract. Int Immunopharmcol. 2011:1:79-84.

9. Yusuf AL, Sazili AQ, Ebrahimi M, Goh YM, Samsudin AA, Idris AB, et al. vitro digestibility of diets containing different parts of Andrographis paniculata using rumen fluid from goats. J Anim Vet Adv. 2012;11:3921-7.

10. Yusuf AL, Goh YM, Samsudin AA, Alimon AR, Sazili AQ. Growth performance, carcass characteristics and meat yield of boer goats fed diets containing leaves or whole parts of Andrographis Paniculata. Asian-Australas. J. Anim Sci. 2014;27:503-10.

11. NRC. Nutrient Requirements of Small Ruminants. Natl. Acad. Press. Washington: DC; 2007

12. AOAC. Official methods of analysis of the Association of Official Analytical Chemists 18th ed. Association of Official Analytical Chemists. Washington D. C.: USA; 2007

13. Van Soest PJ, Robertson J, Lewis B. Methods for dietary fiber, neutral detergent fiber, and nonstarch polysaccharides in relation to animal nutrition. J Dairy Sci. 1991;74:3583-97.

14. Parsons RT, Yoshiaki M, Lalli GM.A manual of chemical and biological methods for seawater analysis. 1st Edn., Pergamon press, Oxford, UK., ISBN: 9780080302874 1984. Pp 173

15. Folch J, Lees M, Sloane-Stanley GA. Simple method for the isolation and purification of total lipids from animal tissues. J Biol Chem. 1957:226:497-509.

16. Adeyemi KD, Sabow AB, Shittu RM, Karim R, Sazili AQ. Influence of dietary canola oil and palm oil blend and refrigerated storage on fatty acids, myofibrillar proteins, chemical composition, antioxidant profile and quality attributes of semimembranosus muscle in goats. J Anim Sci Biotechnol. 2015;6:51.

17. Khaing KT, Loh TC, Ghizan S, Jahromi MF, Halim RA, Samsudin AA. Profiling of rumen fermentation and microbial population changes in goats fed with napier grass supplemented with whole corn plant silage. Asian. J Anim Sci. 2016; doi:10.3923/ajas.2016

18. Koike S, Kobayashi Y. Development and use of competitive PCR assays for the rumen cellulolytic bacteria: Fibrobacter succinogenes, Ruminococcus albus and Ruminococcus flavefaciens. FEMS Microbiol Letter. 2001:204:361-6.

19. Sylvester JT, Karnati SKR, Yu Z, Morrison M, Firkins JL. Development of an assay to quantify rumen ciliate protozoal biomass in cows using real-time PCR. J Nutr. 2004;134:3378-84. 
20. Denman SE, MCSweeney CS. Development of a real time PCR assay for monitoring anaerobic fungal and cellulolytic bacterial populations within the rumen. FEMS Microbiol Ecol. 2006;58:572-82.

21. Lane DJ, Sequencing 16S/23SRRNA. In: Stackebrandt E, Goodfellow M, editors. Nucleic acid techniques in bacterial systematics. New York, NY USA: John Wiley \& Sons; 1991. p. 115-75.

22. SAS User's Guide, 9.2 edn. SAS Inst. Inc, Cary, NC. 2007.

23. Allam SM, Hoda M, El Hosseiny AM, Abdel Gawad SAE, Zeid AMM. Medicinal herbs and plants as feed additives for ruminant. 1. Effect of using some medicinal herbs and plants as feed additives on Zaraibi goat performance. Egypt J Nutr Feed. 1999;1:349-65.

24. Singh B, Chaudhary LC, Agarwal N, Kamra DN. Effect of feeding ficus infectoria leaves on rumen microbial profile and nutrient utilization in goats. Asian-austral. J Anim Sci. 2011;24:810-7.

25. NRC. Ruminant nitrogen usage. National Academy Press. Washington, D.C USA; 1985. p. 138.

26. Leng RA. Factors affecting the utilization of 'poor-quality' forages by ruminants particularly under tropical conditions. Nutr Res Rev. 1990;3:277-303.

27. Min BR, Wood GTAJ, Reilly K, Sun W, Peters JS, Barry TN, et al. Lotus corniculatus condensed tannins decrease in vivo populations of proteolytic bacteria and affect nitrogen metabolism in the rumen of sheep. Can J Microbiol. 2002;48:911-21.

28. Bermingham EN, Hutchinson KJ, Revell DK, Brookes IM, McNabb WC. The effect of condensed tannins in sainfoin (Onobrychisviciifolia) and sulla (Hedysarumcoronarium) on the digestion of amino acids in sheep. Proc New Zealand Soc. Anim Prod. 2001;61:116-9.

29. Abarghuei M, Rouzbehan Y, Alipour D. Effect of oak (quercus libani oliv.) leave tannin on ruminal fermentation of sheep. J Agr. Sci Technol. 2011;13:1021-32.

30. Hungate RE. The rumen and its microbes. New York: Academic Press; 1966. p. 533.

31. Salem A, López S, Ranilla MJ, González JS. Short-to medium-term effects of consumption of quebracho tannins on saliva production and composition in sheep and goats. J Anim Sci. 2013;91:1341-9.

32. Pilajun $\mathrm{R}$, Wanapat $\mathrm{M}$. Effect of coconut oil and mangosteen peel supplementation on ruminal fermentation, microbial population, and microbial protein synthesis in swamp buffaloes. Livest Sci. 2011;141:148-54.

33. Anantasook N, Wanapat M. Influence of rain tree pod meal supplementation on rice straw based diets using in vitro gas fermentation technique. Asian-austral. J Anim Sci. 2012;25:325-34.

34. Adeyemi KD, Sazili AQ, Ebrahimi M, Samsudin AA, Alimon AR, Karim R, et al. Effects of dietary blend of canola oil and palm oil on nutrient intake and digestibility, growth performance, rumen fermentation and fatty acids in goats. Anim Sci J. 2016;89:1137-47.

35. Adeyemi KD, Ebrahimi M, Samsudin AA, Alimon A, Karim R, Karsani SA, et al. Influence of Carotino oil on in vitro rumen fermentation, metabolism and apparent biohydrogenation of fatty acids. Anim Sci J. 2015;86:270-8.

36. Wallace RJ, Chaudhary LC, McKain N, McEwan NR, Richardson AJ, Vercoe PE, et al. Clostridium proteoclasticum: a ruminal bacterium that forms stearic acid from linoleic acid. FEMS Microbiol Letter. 2006;265:195-201.

37. Khiaosa-Ard R, Bryner SF, Scheeder MRL, Wettstein HR, Kreuzer M, Soliva CR. Evidence for the inhibition of the terminal step of ruminal a -linolenic acid biohydrogenation by condensed tannins. J Dairy Sci. 2009:92:177-88.

38. Vasta V, Makkar HPS, Mele M, Priolo A. Ruminal biohydrogenation as affected by tannins in vitro. British. J Nutr. 2009;102:82-92.

39. Cabiddu A, Salis L, Tweed JK, Molle G, Decandia M, Lee MR. The influence of plant polyphenols on lipolysis and biohydrogenation in dried forages at different phenological stages: In vitro study. J Sci Food Agr. 2010;90:829-35.

40. Jayanegara A, Kreuzer M, Wina E, Leiber F. Significance of phenolic compounds in tropical forages for the ruminal bypass of polyunsaturated fatty acids and the appearance of biohydrogenation intermediates as examined in vitro. Anim Prod Sci. 2011;51:1127-36.

41. Tan H, Sieo C, Abdullah N, Liang J, Huang X, Ho Y. Effects of condensed tannins from leucaena on methane production, rumen fermentation and populations of methanogens and protozoa in vitro. Anim Feed Sci Technol. 2011;169:185-93.

42. Baah J, Ivan M, Hristov AN. Effect of potential dietary anti protozoal supplement on rumen fermentation and digestibility in heifers. Anim Feed Sci Technol. 2007;137:129-37.

\section{Submit your next manuscript to BioMed Central and we will help you at every step:}

- We accept pre-submission inquiries

- Our selector tool helps you to find the most relevant journal

- We provide round the clock customer support

- Convenient online submission

- Thorough peer review

- Inclusion in PubMed and all major indexing services

- Maximum visibility for your research

Submit your manuscript at www.biomedcentral.com/submit
Biomed Central 